\title{
A new velocity map for Byrd Glacier, East Antarctica, from sequential ASTER satellite imagery
}

\author{
Leigh STEARNS, Gordon HAMILTON
}

\begin{abstract}
Climate Change Institute, and Department of Earth Sciences, University of Maine, 303 Bryand Global Sciences Center Orono, ME 04469-5790, USA

E-mail: leigh.stearns@maine.edu
\end{abstract}

\begin{abstract}
New ice-velocity measurements are obtained for the main trunk of Byrd Glacier, East Antarctica, using recently acquired Advanced Spaceborne Thermal Emission and Reflection Radiometer (ASTER) imagery. The velocities are derived from the application of a cross-correlation technique to sequential images acquired in 2000 and 2001. Images were co-registered and ortho-rectified with the aid of a digital elevation model (DEM) generated from ASTER stereo imagery. This paper outlines the process of DEM generation, image co-registration and correction, and the application of the crosscorrelation technique to obtain ice velocities. Comparison of the new velocity map with earlier measurements of velocity from 1978 indicates that the glacier has undergone a substantial deceleration between observations. Portions of the glacier flowing at speeds of $\sim 850 \mathrm{~m} \mathrm{a}^{-1}$ in $1978 / 79$ were flowing at $\sim 650 \mathrm{~m} \mathrm{a}^{-1}$ in 2000/01. The cause of this change in ice dynamics is not known, but the observation shows that East Antarctic outlet glaciers can undergo substantial changes on relat ively short timescales.
\end{abstract}

\section{INTRODUCTION}

Large outlet glaciers and ice streams are the primary means by which ice is transported from the interior of Antarctica to the ocean. Relatively small changes in their configuration and flow speed can have significant impacts on icesheet mass balance. Ice streams in West Antarctica are known to change speed on a variety of timescales, ranging from days (Bindschadler and others, 2003) to decades (e.g. Stephenson and Bindschadler, 1988; Joughin and others, 2002; Stearns and others, 2005) through to centuries (Retzlaff and Bentley, 1993). Similar types of behavior are not well characterized for outlet glaciers of the East Antarctic ice sheet, in part because long records of ice dynamics are not widely available. We describe the generation of a new ice-velocity map for Byrd Glacier, one of the largest glaciers in East Antarctica, using modern satellite imagery. The new data are compared with archival measurements of ice velocities to show that large changes in ice dynamics have occurred on this glacier over a period of 22 years.

Byrd Glacier flows through the Transantarctic Mountains and supplies the Ross Ice Shelf with ice from East Antarctica (Fig. 1). Convergent inland sheet flow is funneled through a $\sim 100 \mathrm{~km}$ long, $\sim 20 \mathrm{~km}$ wide fjord. At the fjord's downstream end, linear flow switches to diverging shelf flow as the floating ice enters the Ross Ice Shelf. The glacier has one of the largest catchments in Antarctica $\left(1070400 \mathrm{~km}^{2}\right.$; Rignot and Thomas, 2002), delivers into the Ross Ice Shelf an amount of ice $\left(23.6 \pm 2 \mathrm{~km}^{3} \mathrm{a}^{-1}\right)$ equivalent to that of Whillans Ice Stream (Joughin and Tulaczyk, 2002; Rignot and Thomas, 2002; Stearns and others, 2005) and sustains rapid flow speeds in excess of $650 \mathrm{ma}^{-1}$ (Brecher, 1982). Prolonged changes in the flow dynamics of Byrd Glacier will
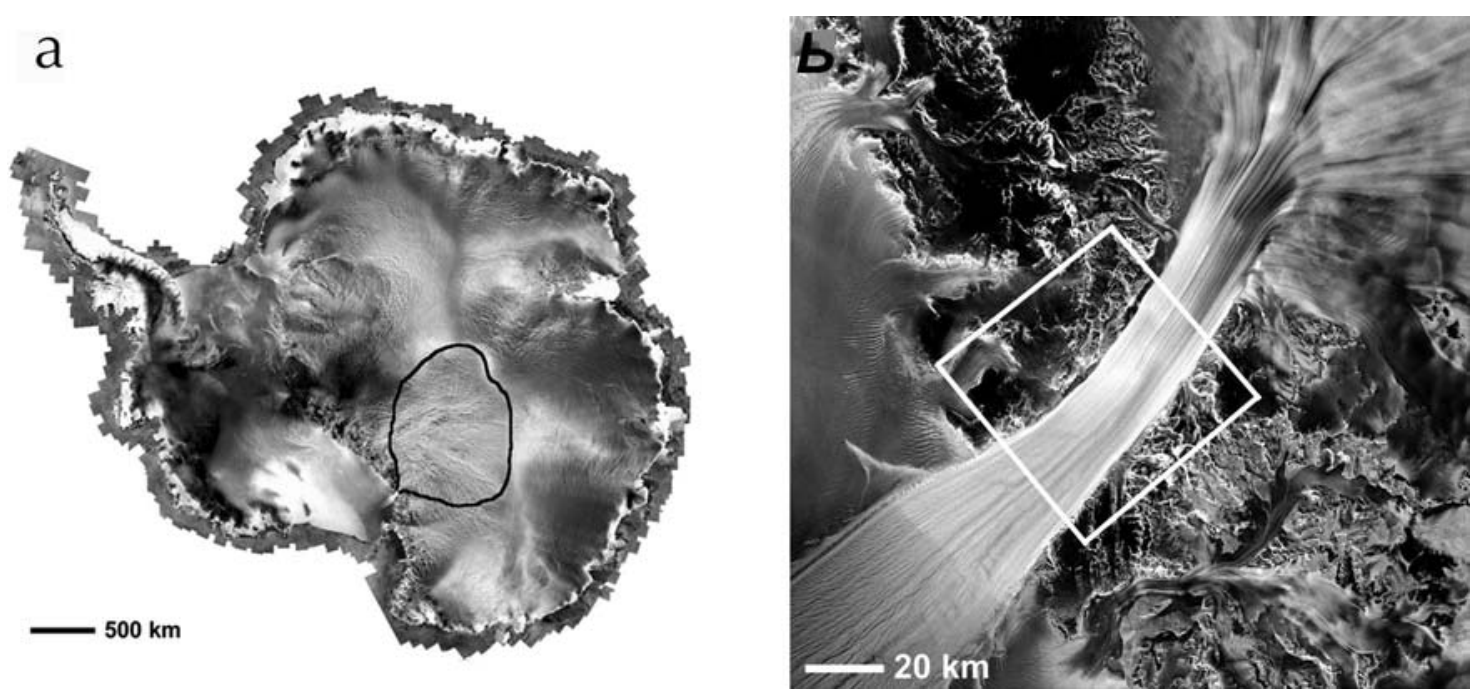

Fig. 1. A RADARSAT image of Byrd Glacier and its catchment. (a) The catchment boundaries are derived from Rignot and Thomas (2002). (b) The location of the ASTER images used in this study to calculate ice velocities. Ice flow is from upper right to lower left. 


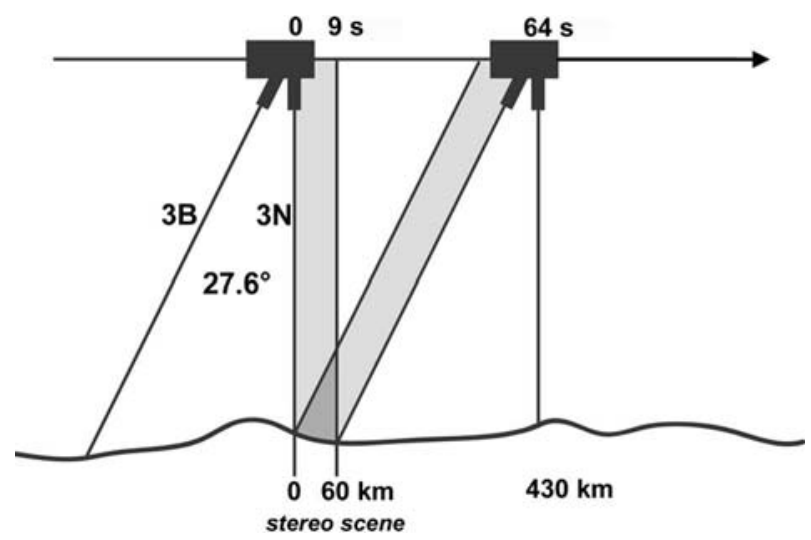

Fig. 2. The acquisition of an ASTER stereo scene (after Kääb, 2002). The $3 \mathrm{~N}$ (nadir band 3) scene and the corresponding 3B (backwardlooking) scene are taken $\sim 60 \mathrm{~s}$ apart (corresponding to $400 \mathrm{~km}$ along the satellite orbit track). These stereo images are used to produce a DEM.

impact the mass balance of East Antarctica and might also affect the stability of the Ross Ice Shelf.

A mass-balance estimate for the entire Byrd Glacier catchment is not currently available because much of the catchment lies beyond the latitudinal range of key spaceborne sensors. Based on mass-budget calculations, Rignot and Thomas (2002) estimate a positive balance for the region of Byrd Glacier north of $\sim 80^{\circ} \mathrm{S}$. Repeat satellite altimetry seems to confirm the positive balance for parts of the Byrd Glacier catchment (Wingham and others, 1998) for the period 1992-96. The balance conditions for the southern portion of Byrd Glacier are unknown (Rignot and Thomas, 2002).

Mass-balance characteristics for most of the East Antarctic outlet glaciers in the Ross Sea embayment are largely unknown but are often assumed to be close to steady state. Fahnestock and others (2000) examined relict flow traces on Advanced Very High Resolution Reflection Radiometer imagery of the Ross Ice Shelf and concluded that the crevasse patterns and flow traces originating from East Antarctica implied steady flow conditions over the last millennium. Frezzotti and others (2000) and Rignot (2002) compared velocity measurements on David Glacier $\left(\sim 75^{\circ} \mathrm{S}\right.$, $\sim 160^{\circ} \mathrm{E}, \sim 550 \mathrm{~km}$ north of Byrd Glacier) with catchmentwide accumulation rates and concluded that the glacier was either in positive balance or maintaining net balance, depending on which accumulation map was used.

Mapping glacier velocities is an important first step in estimating balance conditions. The mass balance of a glacier is often determined by comparing the total net input (by accumulation) with net losses (dominated by ice flow) (e.g. Whillans and Bindschadler, 1988; Bindschadler and others, 1996; Joughin and others, 2002; Rignot, 2002). This method requires accurate ice-velocity measurements, snow accumulation rates and, depending on the approach, catchment dimensions and the ice thickness at an exit gate. The tracking of features, such as crevasses and rifts, on sequential visible images is an efficient method for obtaining ice surface velocity measurements in remote regions (Lucchitta and Ferguson, 1986). An automated version of this technique has been applied to several different types of satellite imagery (e.g. Bindschadler and Scambos, 1991; Whillans and others, 1993; Lucchitta and others, 1995; Kääb and Vollmer, 2000; Kääb, 2002; Stearns and others, in press).
As part of an effort to characterize the mass balance of outlet glaciers draining East Antarctica through the Transantarctic Mountains, we have applied the feature-tracking routine to sequential pairs of recent satellite images acquired by the Advanced Spaceborne Thermal Emission and Reflection Radiometer (ASTER) sensor to obtain maps of outlet glacier velocity. In this paper, we outline the methods involved in producing a new velocity map for Byrd Glacier, including digital elevation model (DEM) generation using along-track stereo scenes, image ortho-rectification, and application of cross-correlation techniques. The resulting velocity map is compared with an earlier map of surface velocities obtained in 1978 to show that Byrd Glacier has undergone significant changes in flow dynamics over the past two decades.

\section{VELOCITY MAPPING USING ASTER IMAGERY}

The ASTER sensor on board the Terra satellite launched in December 1999 provides new opportunities for glacier mapping in high-latitude regions (to $\sim 85^{\circ} \mathrm{N} / \mathrm{S}$ ) (Yamaguchi and others, 1998). ASTER is a high-resolution, multispectral sensor with $15 \mathrm{~m}$ ground resolution in the visible/nearinfrared (VNIR) bands. Additional spectral capabilities include several lower-resolution $(30-90 \mathrm{~m})$ bands at shortwave infrared and thermal wavelengths. The high-resolution VNIR bands make ASTER imagery ideal for measuring feature displacement in sequential images (e.g. Kääb, 2002; Toutin, 2002b; Stearns and others, in press).

The ASTER instrument acquires stereo imagery using a nadir $(3 \mathrm{~N})$ and backward (3B) viewing telescope in the NIR band 3 (Yamaguchi and others, 1998). The backwardlooking telescope points $27.6^{\circ}$ off-nadir (Fig. 2). Together, bands $3 \mathrm{~N}$ and $3 \mathrm{~B}$ can be used to produce a $15 \mathrm{~m}$ horizontalresolution DEM of a $60 \mathrm{~km} \times 60 \mathrm{~km}$ scene. DEMs are useful as a means of co-registering image pairs in regions of highrelief terrain, such as in the present outlet-glacier application where conventional ground control is limited.

DEM generation from stereo satellite imagery is not a new technique (e.g. Ehlers and Welch, 1987; Grabmaier and others, 1988; Toutin, 2002a, b; Zomer and others, 2002; Eldhuset and others, 2003; Paul and others, 2004). The advantage of ASTER stereo imagery is that images with the necessary different viewing angles are acquired nearly simultaneously ( $60 \mathrm{~s}$ apart), rather than days or months apart as with other image types. This eliminates the problem of surface decorrelation (due to snowfall, melting, etc.) inherent in the other techniques (Kääb, 2002; Toutin, 2002b).

Our objective is to produce ice-velocity maps for outlet glaciers draining through the rugged terrain of the Transantarctic Mountains. Velocities are derived from automatic tracking of surface features on sequential ASTER images using IMCORR, an established cross-correlation technique (Scambos and others, 1992). The IMCORR technique was originally developed for mapping displacements on lowslope ice streams in West Antarctica (Scambos and others, 1992) from Landsat imagery. Characteristics of the ASTER sensor and the application of the technique to rugged terrain necessitate several modifications.

Sequential stereo pairs used for cross-correlation must be largely cloud-free, and are required to have similar illumination characteristics (Scambos and others, 1992). The ASTER instrument's across-track, off-nadir scene acquisition capability $\left( \pm 8.55^{\circ}\right)$ introduces an image geometry 


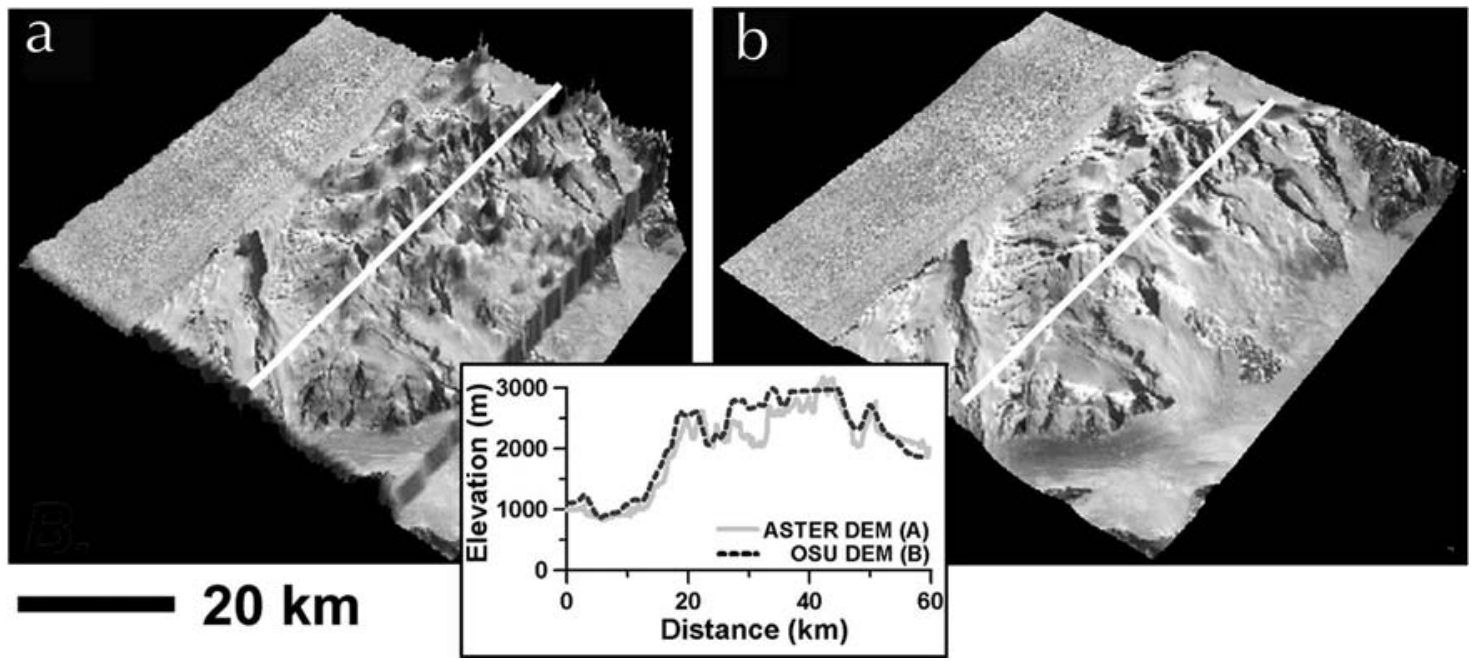

Fig. 3. (a) An ASTER image draped over the ASTER-derived DEM of the Byrd Glacier area. The drop in elevation at the right of the image is due to the lack of overlap between the $3 \mathrm{~N}$ and $3 \mathrm{~B}$ bands (caused by the slight difference in look angle). Flow is from right to left. (b) The same ASTER image draped over the OSU DEM (Liu and others, 1999). The elevation profile follows the thick white line in (a) and (b). The solid line is elevation data from the ASTER DEM; the dashed line is from the OSU DEM. Note the improved spatial resolution of the ASTER DEM.

change that must be considered during scene selection. Over regions of rugged relief such as the Transantarctic Mountains, we find that the pointing angles of sequential images need to be within $3^{\circ}$ to maintain similar geometric characteristics. If the pointing-angle difference is $>3^{\circ}$, panoramic distortion inhibits cross-correlation. A further consideration is the time interval between sequential image acquisition. The time separation must be long enough for features to be displaced more than the measurement uncertainties, but not so long that features are distorted beyond recognition. In the present case, the optimal separation interval is about 3-12 months.

\section{PROCESSING METHODS}

Several image preparation steps are required before running the feature-tracking technique. These steps are used to orthorectify and co-register the image pair, and are necessary because conventional ground control is not widely available for the Byrd Glacier region and because an existing DEM of the study area (the OSU DEM; Liu and others, 1999) does not provide enough detail. The resolution of the OSU DEM, which combines satellite-, ground- and airborne-based Antarctic elevation data, depends on the density and scale of the source data and the ruggedness of the topography. Over Byrd Glacier, where the terrain is rough and the data distribution is only average, the horizontal resolution is $\sim 200 \mathrm{~m}$ and the vertical accuracy is $\sim 100 \mathrm{~m}$ (Liu and others, 1999, 2001).

An ASTER-based DEM was generated using bands $3 \mathrm{~N}$ and 3B of a single level 1B ASTER scene (ID \#AST_L1B_ 003_12132000191929_02152003105014). Processing of the stereo bands was done using PCl Geomatica 9.1 ${ }^{\circledR}$ software, following methods outlined by Toutin (2001, 2002b) and Toutin and Cheng (2001). Geolocation of the images was based on the satellite ephemeris data given in the Hierarchical Data Format (HDF) metadata file. To supplement the corner coordinates, 18 tie points between the $3 \mathrm{~N}$ and $3 \mathrm{~B}$ scenes were manually selected. Transformation to epipolar geometry and parallax-matching was done automatically with PCl software (Toutin and Cheng, 2001;
Kääb and others, 2003), and a relative DEM was produced through parallax-to-DEM conversion (Fig. 3). The improved vertical resolution of the ASTER-derived DEM is evident in a comparison (Fig. 3) with the existing OSU DEM. The detail of topography in the ASTER DEM is much clearer than the OSU DEM, which tends to smooth out sharp peaks and ridges.

The new ASTER DEM was used to ortho-rectify the image pair prior to feature matching. Ortho-rectification is the correction of an image, pixel-by-pixel, for topographic distortion due to Earth's curvature and terrain elevation. This process is especially important near Byrd Glacier because the rugged terrain of the Transantarctic Mountains has an elevation range of $\sim 3500 \mathrm{~m}$, and the relatively steep slopes introduce errors in scaling horizontal distances. Absolute ortho-rectification requires a detailed DEM and ground-control points (GCPs), but neither is readily available for the Byrd Glacier region. A relative DEM and relative GCPs are sufficient for ortho-rectification in the present case (assuming images are accurately co-registered to each other), because our primary application is the relative displacement of surface features.

Accurate ortho-rectification was achieved with the highresolution ASTER DEM by using the lower-resolution OSU DEM as a baseline for parallax matching. Parallax matching is a step in the ortho-rectification process that removes the apparent change in relative positions of stationary objects, i.e. mountains, caused by a change in viewing position from the satellite. Parallax matching produces a pair of epipolar ortho-images that are then used to produce a DEM. The OSU DEM provided a predefined baseline elevation which allowed the relative positions of the mountains to be calculated correctly.

Once the images were co-registered and ortho-rectified, a principal component filter was applied to both scenes to reduce image noise. In multiband images, the first principal component of the visible data produces images in which ice topography is enhanced and subtle reflectance differences in snow type (between snow and firn) are suppressed (Scambos and others, 1992). Additional noise suppression techniques that Scambos and others (1992) applied to Landsat scenes, such as scan-line de-striping, high-pass filtering and 


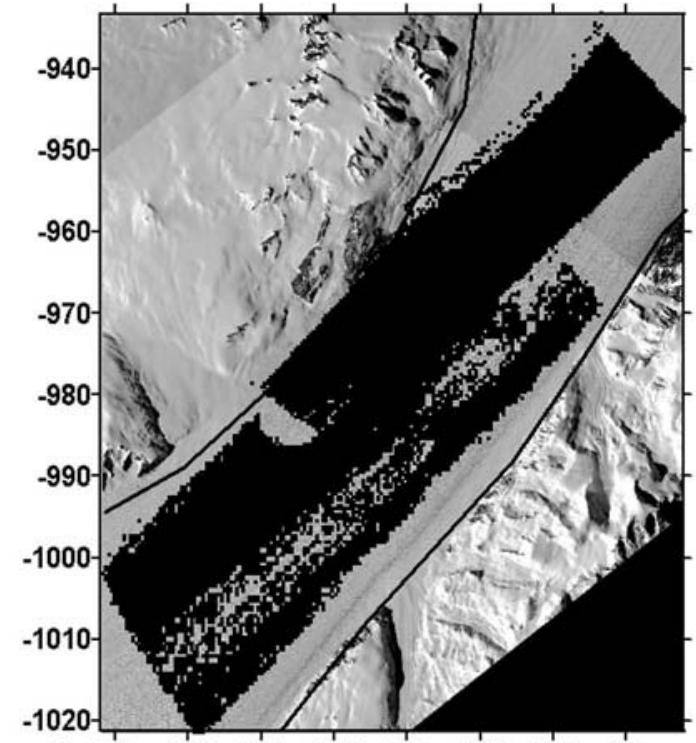

a $\begin{array}{llllllll}340 & 350 & 360 & 370 & 380 & 390 & 400 & 410\end{array}$

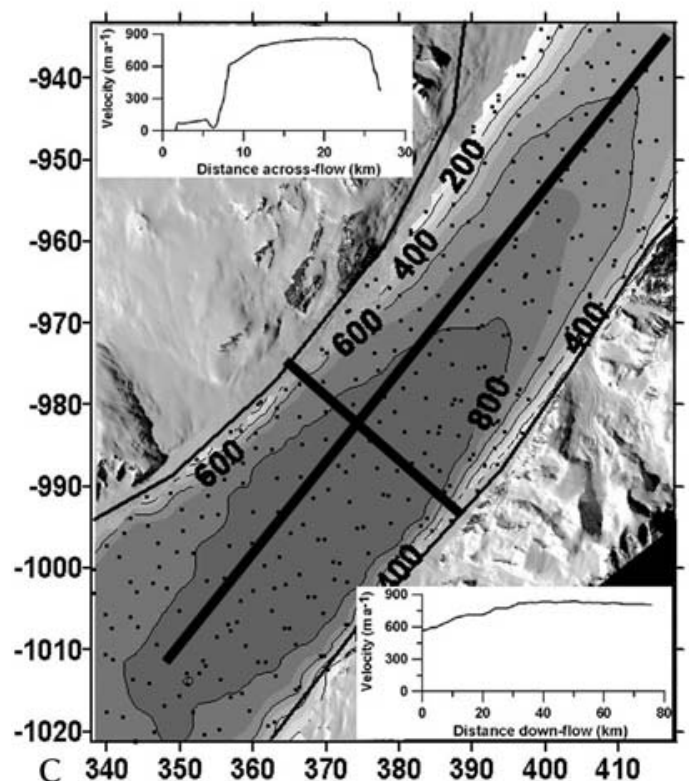

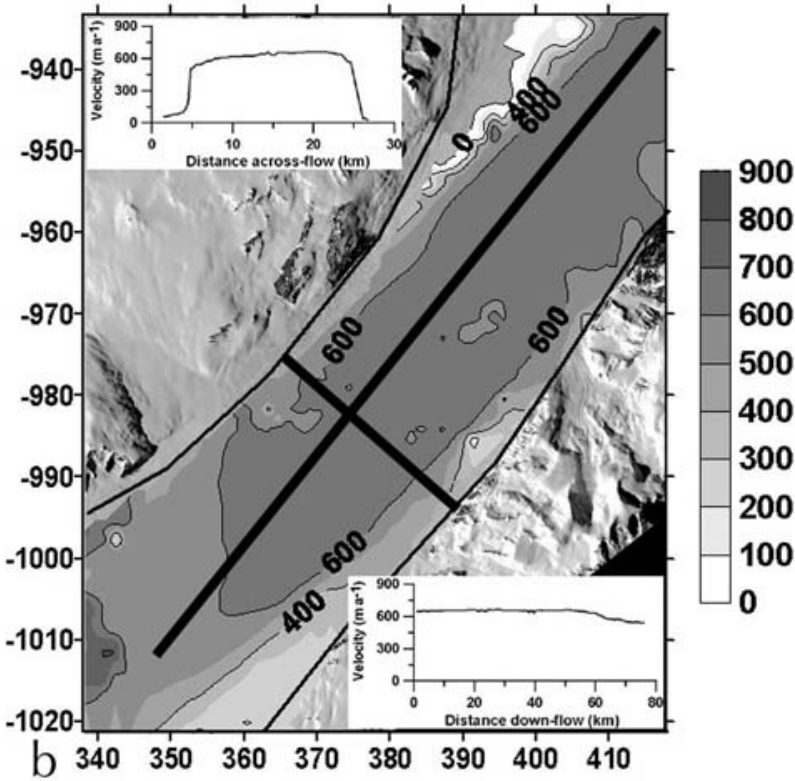

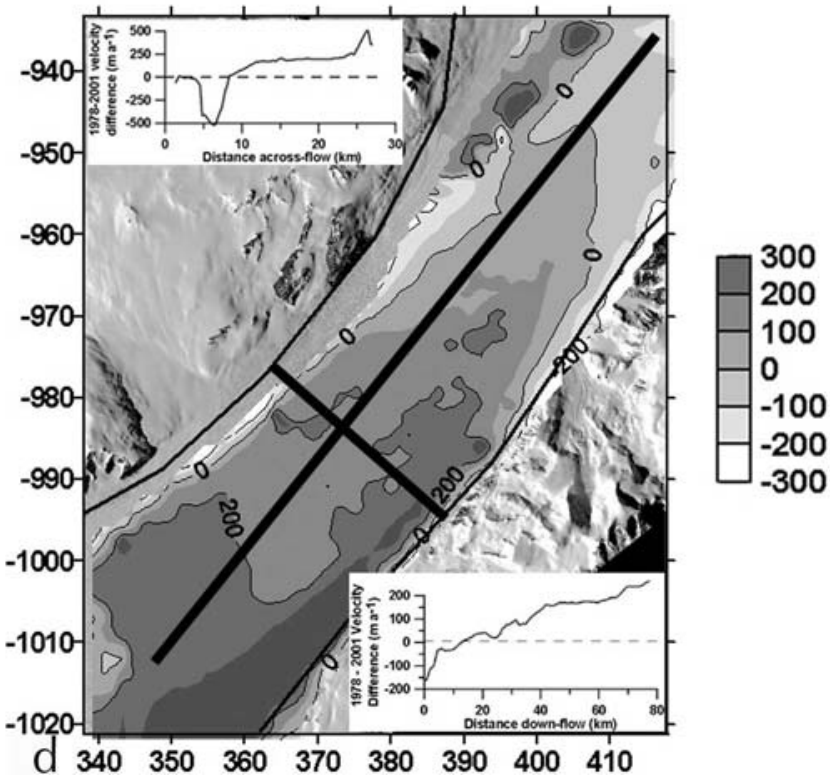

Fig. 4. (a) The distribution of displacement vectors from feature tracking using ASTER imagery. (b) The new velocity map for Byrd Glacier as obtained from ASTER, and gridded to $1 \mathrm{~km}$. The velocity profiles correspond to the thick black lines along and across the image. (c) The velocity map derived by Brecher (1982) from aerial photography. (d) The difference in velocities (2001/02 - 1978/79) between maps B and C.

Gaussian contrast stretching, were not necessary for preparation of the ASTER imagery.

The cross-correlation algorithm (IMCORR) was then applied to the prepared images. Features were matched between the two sequential images, and their displacement calculated. Bad matches were discarded on the basis of a correlation strength estimate. The result is a dense array of displacement measurements for many (>13 000) points on the glacier surface (Fig. 4a). To test the accuracy of the coregistration, the feature-tracking algorithm confirmed that stationary bedrock features on the adjacent mountains did not move between the sequential images.

\section{RESULTS}

The methods described above were applied to two ASTER scenes of Byrd Glacier, acquired on 13 December 2000 and
13 November 2001. Approximately 13250 displacements were obtained (Fig. 4a), contrasting the 470 data points produced with photogrammetry in 1978 (Fig. 4c) (Brecher, 1982). Both velocity datasets were gridded at $1 \mathrm{~km}$ spacing, using the kriging method, to produce contoured surface velocity maps (Fig. $4 \mathrm{~b}$ and c). Changes in ice velocity from 1978 to 2001 are shown in Figure 4d. Velocity profiles (following the thick black lines in Fig. 4b-d) of the gridded data show ice-flow patterns both along and across the glacier.

In 1978 and 2001, a wide zone in the center of the glacier flows at a speed of $650-850 \mathrm{~m} \mathrm{a}^{-1}$ (Fig. $4 \mathrm{~b}$ and c). The lateral reduction in velocity occurs rapidly within a narrow band, $<1 \mathrm{~km}$ wide, adjacent to each margin. This type of transverse velocity profile is similar to those measured on ice streams in West Antarctica (e.g. Joughin and others, 2002; Stearns and others, 2005), whereas other fast-flowing, rock-bounded 
glaciers are characterized by narrow bands of peak flow speeds near the center of the channel (e.g. Van der Veen, 1999, p. 118).

The longitudinal velocity profile indicates that peak flow speeds are reached soon after Byrd Glacier enters the fjord (Fig. $4 \mathrm{~b}$ and c). There appears to be a region of reduced flow velocity near the downstream portion of the study area, where the velocity decelerates 23.5\% from 1978 to 2001 (Fig. 4d). The sequential image coverage does not extend any farther downstream, so we cannot characterize the velocity pattern of Byrd Glacier as it enters the Ross Ice Shelf.

\section{SOURCES OF UNCERTAINTY}

The measured displacements of surface features have several sources of uncertainty. The major sources are DEM generation, image ortho-rectification, co-registration and application of the matching technique.

Generation of the ASTER DEM introduces an uncertainty that is difficult to assess because alternative high-resolution DEMs and accurate GCPs of Byrd Glacier are not available. Other studies have compared ASTER DEMs with DEMs produced by conventional photogrammetry for mountain regions in the Swiss Alps and New Zealand. In such cases, uncertainties in absolute elevations can be quite large ( $\sim 60 \mathrm{~m} \mathrm{rms}$ ) for rugged topography (e.g. Kääb, 2002). The uncertainties in relative elevations, important for the present study, are usually much smaller. Stevens and others (2004) note that, in the absence of appreciable atmospheric water vapor, rms uncertainties for relative ASTER DEMs are $<10 \mathrm{~m}$ for moderately rugged terrain. This estimate is probably valid for the Transantarctic Mountains, where very dry atmospheric conditions prevail.

Ortho-rectification using the ASTER DEM translates the DEM errors onto the ortho-rectified image. Following Kääb's (2002) results in the Swiss Alps, a $10 \mathrm{~m}$ ground position error is expected for rough terrain and a $3 \mathrm{~m}$ error is expected for moderate terrain (Kääb, 2002). Overall, resampling errors during ortho-projection translate to positional errors that are at the sub-pixel $(<15 \mathrm{~m})$ level.

Uncertainties associated with the image cross-correlation technique are smaller than the pixel size of $15 \mathrm{~m}$. Matches with uncertainties larger than 1 pixel were discarded. Cumulatively, the uncertainties resulting from all error sources are $\sim 20 \mathrm{~m}$ (which translate to velocity uncertainties of $\sim 21 \mathrm{~m} \mathrm{a}^{-1}$ ) and are unimportant for the fast glacier speeds $\left(>400 \mathrm{~m} \mathrm{a}^{-1}\right)$ being investigated here.

\section{DISCUSSION}

The new velocity map is compared with an earlier compilation of ice velocities derived from conventional photogrammetry performed on aerial photographs acquired in 1978 and 1979 (Fig. 4d; Brecher, 1982). In 1978/79, the peak velocities were $\sim 850 \mathrm{~m} \mathrm{a}^{-1}$. The new results show that 22 years later, the fastest velocities in the same area were closer to $650 \mathrm{~m} \mathrm{a}^{-1}$, a $23.5 \%$ deceleration. The deceleration is most pronounced in the downstream portion of the studied area (Fig. 4d), implying that the deceleration originated down-glacier and is migrating up-glacier. There does not appear to have been significant deceleration in the upstream portion of the image.
The deceleration appears to be a relatively recent event. Flow speeds measured by Brecher (1982) are consistent with point measurements of velocity obtained in 1962 by conventional triangulation surveys (Swithinbank, 1963). In addition, manual tracking of large transverse surface rifts in satellite images from 1974 and 1983 yielded a 10 year average velocity (Lucchitta and Ferguson, 1986) that was very similar to the 1 year average reported by Brecher (1982). These observations indicate that the flow of Byrd Glacier was steady between $\sim 1962$ and 1983 .

There is evidence suggesting that Byrd Glacier is undergoing large-scale changes in ice dynamics. Reusch and Hughes (2003) estimate that the grounding zone migrated $\sim 20 \mathrm{~km}$ upstream between 1979 (Hughes and Fastook, 1981) and 1997 (Rignot and Jacobs, 2002). The 1979 grounding zone corresponds to the part of the glacier where deceleration was most pronounced (Fig. 4d). According to Reusch and Hughes (2003), this region is not completely afloat. It is not known whether the deceleration in flow speeds and grounding line migration are linked events. A deceleration might imply that the supply of ice to the grounding line is insufficient to maintain a stable position, leading to retreat. Alternatively, an increase in basal melting (Rignot and Jacobs, 2002) might account for the inland retreat of the grounding line. Whatever the cause, it is not clear why flow speeds should decrease in a part of the glacier that became decoupled from its bed.

Reusch and Hughes (2003) also note the presence of lowamplitude ( $\sim 50 \mathrm{~m})$, long-wavelength $(10-20 \mathrm{~km})$ 'waves' on the surface of Byrd Glacier. These features are the result of longitudinal variations in ice thickness and are visible in elevation maps made from photogrammetry (Brecher, 1980). One explanation for their occurrence is temporal changes in the nature of subglacial coupling (Reusch and Hughes, 2003). Changes in the basal boundary condition should lead to fluctuations in surface flow speeds. It is possible that the observed deceleration in velocity is consistent with the formation of 'waves' on Byrd Glacier.

\section{CONCLUSIONS}

Feature tracking using high-resolution ASTER satellite imagery is an efficient way of deriving maps of surface velocity on interesting parts of East Antarctic outlet glaciers. The stereo imaging capability of the ASTER sensor enables the generation of high-resolution DEMs that can be used to coregister and ortho-rectify images in regions of rugged topography where other survey data are not available.

The technique is applied to images of Byrd Glacier, acquired in 2000 and 2001, to yield a dense map of velocity vectors. The glacier is characterized by a wide zone of sustained fast flow speeds in excess of $600 \mathrm{~m} \mathrm{a}^{-1}$. Nearly all the lateral reduction in flow velocities occurs in a narrow band close to each margin.

A comparison of the 2000/01 velocity field with an earlier map of ice flow in 1978/79 shows that Byrd Glacier has undergone a significant deceleration over the 22 year period. Peak speeds have slowed from $\sim 850 \mathrm{ma}^{-1}$ to $\sim 650 \mathrm{ma}^{-1}$. This deceleration might be related to other indications of changes on Byrd Glacier, such as grounding line migration and the formation of surface waves. Taken together, these observations show that the flow behavior of this large East Antarctic outlet glacier is complex and dynamic. 


\section{ACKNOWLEDGEMENTS}

This work was supported by NASA's Cryospheric Sciences Program through NAG5-9913. We thank B. Raup, D. Fatland, F. Paul and D. Vaughan for their careful and constructive comments on the manuscript.

\section{REFERENCES}

Bindschadler, R.A. and T.A. Scambos. 1991. Satellite-imagederived velocity field of an Antarctic ice stream. Science, 252(5003), 242-246.

Bindschadler, R., P. Vornberger, D. Blankenship, T. Scambos and R. Jacobel. 1996. Surface velocity and mass balance of Ice Streams D and E, West Antarctica. J. Glaciol., 42(142), 461-475.

Bindschadler, R.A., M.A. King, R.B. Alley, S. Anandakrishnan and L. Padman. 2003. Tidally controlled stick-slip discharge of a West Antarctic ice stream. Science, 301(5636), 1087-1089.

Brecher, H.H. 1980. Apparent surface lowering of the Byrd Glacier between 1960 and 1978. Antarct. J. US, 15(5), 64-65.

Brecher, H.H. 1982. Photographic determination of surface velocities and elevations on Byrd Glacier. Antarct. J. US, 17(5), 79-81.

Ehlers, M. and R. Welch. 1987. Stereocorrelation of Landsat TM images. Photogramm. Eng. Remote Sens., 53(9), 1231-1237.

Eldhuset, K., P.H. Anderson, S. Hague, E. Isakksson and D.J. Weydahl. 2003. ERS tandem InSAR processing for DEM generation, glacier motion estimation and coherence analysis on Svalbard. Int. J. Remote Sens., 24(7), 1415-1437.

Fahnestock, M.A., T.A. Scambos, R.A. Bindschadler and G. Kvaran. 2000. A millennium of variable ice flow recorded by the Ross Ice Shelf, Antarctica. J. Glaciol., 46(155), 652-664.

Frezzotti, M., I.E. Tabacco and A. Zirizzotti. 2000. Ice discharge of eastern Dome C drainage area, Antarctica, determined from airborne radar survey and satellite image analysis. J. Glaciol., 46(153), 253-264.

Grabmaier, K., A.M. Tuladhar and T.H. Verstappen. 1988. Stereo mapping with SPOT. ITC Journal, 2, 149-154.

Hughes, T.J. and J.L. Fastook. 1981. Byrd Glacier: 1978-1979 field results. Antarct. J. US, 16(5), 86-89.

Joughin, I. and S. Tulaczyk. 2002. Positive mass balance of the Ross ice streams, West Antarctica. Science, 295(5554), 476-480.

Joughin, I., S. Tulaczyk, R.A. Bindschadler and S. Price. 2002. Changes in West Antarctic ice stream velocities: observation and analysis. J. Geophys. Res., 107(B11), 2289. (10.1029/ 2001JB001029.)

Kääb, A. 2002. Monitoring high-mountain terrain deformation from repeated air- and spaceborne optical data: examples using digital aerial imagery and ASTER data. ISPRS J. Photogramm. Remote Sens, 57(1-2), 39-52.

Kääb, A. and M. Vollmer. 2000. Surface geometry, thickness changes and flow fields on permafrost streams: automatic extraction by digital image analysis. Permafr. Periglac. Proc., 11(4), 315-326.

Kääb, A. and 6 others. 2003. Glacier monitoring from ASTER imagery: accuracy and application. EARSeL eProceedings, 2(1), 43-53.

Liu, H., K.C. Jezek and B. Li. 1999. Development of an Antarctic digital elevation model by integrating cartographic and remotely sensed data: a geographic information system based approach. J. Geophys. Res., 104(B10), 23,199-23,213.

Liu, H., K.C. Jezek, B. Li and Z. Zhao. 2001. RADARSAT Antarctic Mapping Project digital elevation model version 2. Boulder, CO, National Snow and Ice Data Center.

Lucchitta, B.K. and H.M. Ferguson. 1986. Antarctica: measuring glacier velocity from satellite images. Science, 234(4780), 1105-1108.
Lucchitta, B.K., C.E. Rosanova and K.F. Mullins. 1995. Velocities of Pine Island Glacier, West Antarctica, from ERS-1 SAR images. Ann. Glaciol., 21, 277-283.

Paul, F., C. Huggel and A. Kääb. 2004. Combining satellite multispectral image data and a digital elevation model for mapping debris-covered glaciers. Remote Sens. Environ., 89, 510-518.

Retzlaff, R. and C.R. Bentley. 1993. Timing of stagnation of Ice Stream C, West Antarctica, from short-pulse radar studies of buried surface crevasses. J. Glaciol., 39(133), 553-561.

Reusch, D. and T.J. Hughes. 2003. Surface 'waves' on Byrd Glacier, Antarctica. Antarct. Sci., 154(4), 547-555.

Rignot, E. 2002. Mass balance of East Antarctic glaciers and ice shelves from satellite data. Ann. Glaciol., 34, 217-227.

Rignot, E. and S.S. Jacobs. 2002. Rapid bottom melting widespread near Antarctic ice sheet grounding lines. Science, 296(5575), 2020-2023.

Rignot, E. and R.H. Thomas. 2002. Mass balance of polar ice sheets. Science, 297(5586), 1502-1506.

Scambos, T.A., M.J. Dutkiewicz, J.C. Wilson and R.A. Bindschadler. 1992. Application of image cross-correlation to the measurement of glacier velocity using satellite image data. Remote Sens. Environ., 42(3), 177-186.

Stearns, L.A., K.C. Jezek and C.J. van der Veen. 2005. Decadal scale variations in ice flow along Whillans Ice Stream and its tributaries, West Antarctica. J. Glaciol., 51(172), 147-157.

Stearns, L.A., G.S. Hamilton and N. Reeh. In press. Multi-decadal record of ice dynamics on Daugaard Jensen Gletscher, East Greenland, from satellite imagery and terrestrial measurements. Ann. Glaciol.

Stephenson, S.N. and R.A. Bindschadler. 1988. Observed velocity fluctuations on a major Antarctic ice stream. Nature, 334(6184), 695-697.

Stevens, N., H. Garbeil and P.J. Mouginis-Mark. 2004. NASA EOS Terra ASTER: volcanic topographic mapping and capability. Remote Sens. Environ., 90(3), 405-414.

Swithinbank, C.W. 1963. Ice movement of valley glaciers flowing into the Ross Ice Shelf, Antarctica. Science, 141(3580), 523-524.

Toutin, T. 2001. Elevation modelling from satellite VIR data: a review. Int. J. Remote Sens., 22(6), 1097-1225.

Toutin, T. $2 \overline{002 a . ~ D E M ~ f r o m ~ s t e r e o ~ L a n d s a t ~} 7$ ETM + data over high relief areas. Int. J. Remote Sens., 23(10), 2133-2139.

Toutin, T. 2002b. Three-dimensional topographic mapping with ASTER stereo data in rugged topography. IEEE T. Geosci. Remote, 40(10), 2241-2247.

Toutin, T. and P. Cheng. 2001. DEM generation with ASTER stereo data. Earth Observation Magazine, 10(6), 10-13.

Van der Veen, C.J. 1999. Fundamentals of glacier dynamics. Rotterdam, etc., A.A. Balkema Publishers.

Whillans, I.M. and R.A. Bindschadler. 1988. Mass balance of Ice Stream B, West Antarctica. Ann. Glaciol., 11, 187-193.

Whillans, I.M., M. Jackson and Y.H. Tseng. 1993. Velocity pattern in a transect across Ice Stream B, Antarctica. J. Glaciol., 39(133), 562-572.

Wingham, D.J., A.L. Ridout, R. Scharroo, R.J. Arthern and C.K. Shum. 1998. Antarctic elevation change 1992 to 1996. Science, 282(5388), 456-458.

Yamaguchi, Y., A.B. Kahle, H. Tsu, T. Kawakami and M. Pniel. 1998. Overview of Advanced Spaceborne Thermal Emission and Reflection Radiometer (ASTER). IEEE T. Geosci. Remote, 36(4), 1062-1071.

Zomer, R., S. Ustin and J. Ives. 2002. Using satellite remote sensing for DEM extraction in complex mountainous terrain: landscape analysis of the Makalu Barun National Park of eastern Nepal. Int. J. Remote Sens., 23(1), 125-143. 